\title{
Studi Eksperimental Micro Deep Drawing Sistem Pneumatik dan Analisis Cacat Pada Material Brass 70/30
}

\author{
R. Diwihagso* dan M. Mahardika \\ Departemen Teknik Mesin dan Industri, Fakultas Teknik, Universitas Gadjah Mada \\ Jalan Grafika No. 2 Yogyakarta 55281 Telp. +62-274-521673 \\ E-mail: *1 montevinar@gmail.com
}

\begin{abstract}
Abstrak
Microforming adalah merupakan salah satu teknologi kunci untuk tren miniaturisasi produk di bidang industri. Teknologi Micro deep drawing memiliki banyak keunggulan seperti kemampuan untuk mengolah logam dengan potensi produksi masal, kualitas produk yang tinggi dan fabrikasi produk logam 3D yang lebih rumit. Penelitian ini bertujuan untuk membuat cup dari material brass untuk dianalisis kedalaman cup dan cacat akibat di pengaruh besarnya tekanan dan kecepatan punch dalam proses micro deep drawing. Studi eksperimental ini meliputi tahap persiapan material brass C26000 yang berupa lembaran dipotong menjadi strip untuk dibuat blank, pembuatan specimen untuk tensile test dan mikrostruktur, membuat desain punch dan die untuk di manufaktur, eksperimen proses micro deep drawing dari blank menjadi bentuk cup dan analisis cacat, data kedalaman cup, prosentase penipisan dinding сир dari hasil eksperimental. Dalam studi ini telah dilakukan ekperimental dengan variasi tekanan kompresor angin sebesar 2, 4, 6 Bar dan kecepatan drawing sebesar $20 \mathrm{~mm} / \mathrm{s}, 40 \mathrm{~mm} / \mathrm{s}, 60 \mathrm{~mm} / \mathrm{s}$. Kesimpulan studi eksperimental ini adalah proses micro deep drawing telah dilakukan telah menghasilkan cup dengan kedalaman optimum pada tekanan 2 bar dengan kecepatan $40 \mathrm{~mm} / \mathrm{s}$ didapatkan $\mathrm{Hl}=2,595 \mathrm{~mm}$ dan $\mathrm{Hs}$ $=2,265 \mathrm{~mm}$. Hasil tersebut merupakan hasil terbaik karena tidak terdapat cacat pada sisi dinding maupun bawah cup.
\end{abstract}

Kata kunci: micro deep drawing, punch dan die, tekanan dan kecepatan.

\begin{abstract}
Microforming is one of the key technologies for product miniaturization trends in the industrial field. Micro deep drawing technology has many advantages such as the ability to process metals with mass production potential, high product quality and fabrication of more complicated $3 D$ metal products. This study aims to make a cup from brass material to be analyzed for cup depth and defects due to the influence of the amount of pressure and punch velocity in drawn blanks. This experimental study includes the preparation phase of C26000 brass material in the form of sheets cut into strips to be made blank, making specimens for tensile tests and microstructures, making punch and die designs for manufacturing, experimenting with micro deep drawing processes from blanks to cup shapes and defect analysis, cup depth data, percentage of cup wall depletion from experimental results. In this study, an experimental variation of angina compressor pressure of 2, 4, 6 Bar and drawing velocity of $20 \mathrm{~mm} / \mathrm{s}, 40 \mathrm{~mm} / \mathrm{s}, 60 \mathrm{~mm} / \mathrm{s}$ has been carried out. The conclusion of this experimental study is that the process of micro deep drawing has been carried out to produce a cup with optimum depth at 2 barpressure with a velocity of $40 \mathrm{~mm} / \mathrm{s}$ obtained $\mathrm{Hl}=2.595 \mathrm{~mm}$ and $H s=2.265 \mathrm{~mm}$. These results are the best results because there are no defects on the sides of the wall or under the cup.
\end{abstract}


Keywords: micro deep drawing, punch dan die, pressure dan velocity.

\section{PENDAHULUAN}

Pasar global untuk sistem mikro-elektromekanis, yang mencakup produk-produk seperti airbag system, display system dan kartrid inkjet berjumlah \$ 62 juta pada tahun 2006 menurut Global MEMS / Microsystems Markets and Opportunities, sebuah laporan penelitian dari SEMI dan diperkirakan akan mencapai \$ 138 juta pada 2019. Dalam beberapa tahun terakhir permintaan akan komponen mikrometalik terus menerus meningkat bersamaan dengan pesatnya perkembangan mikroelektronika, teknologi mikrosistem, energi baru, dan biomedis.

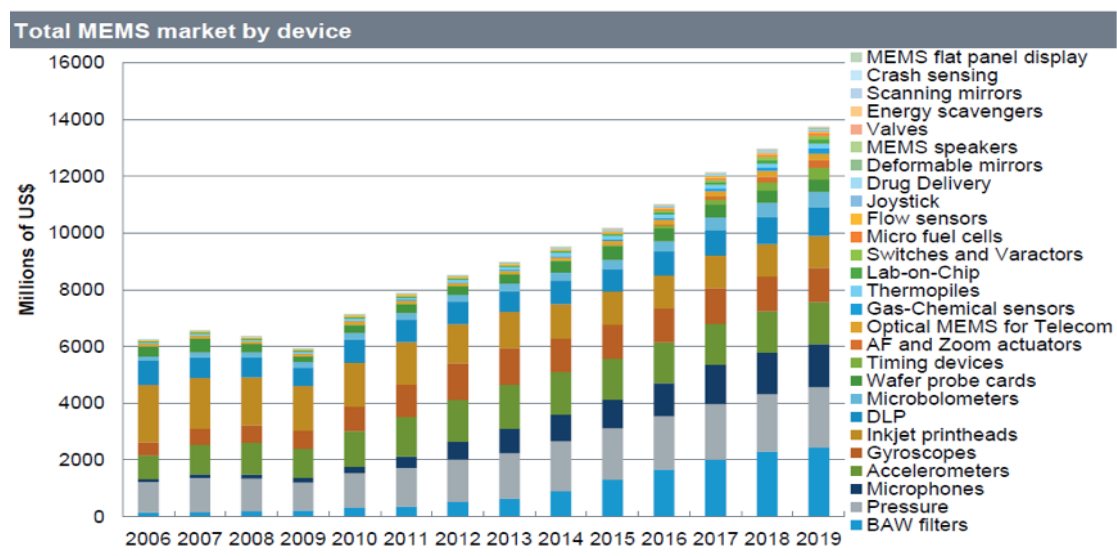

Gambar 1. Perkiraan pasar produk tertentu dengan komponen mikro

(sumber : https://semiengineering.com/health-growth-ahead-in-mems, 17 juni 2019)

Menurut Fu dan Chan (2013) perkembangan cepat miniaturisasi produk telah mendorong penelitian signifikan di bidang microforming, terutama dalam produksi komponen mikro untuk mengurangi berat dan volumenya. Berbeda dari proses pembentukan dalam skala makro, perilaku deformasi material dalam proses pembuatan mikro tidak dapat hanya dipahami dengan pengetahuan tradisional karena efek skala mikro. Karena itu, untuk memberikan pemahaman yang mendalam tentang perilaku material dalam deformasi plastis dalam skala mikro banyak upaya telah dilakukan dalam proses microforming khas seperti micro deep drawing, blanking, bulging, stamping, forging.

Menurut Sridhar dkk (2015) faktor penting dalam proses pembentukan mikro adalah Blank holder force (BHF) dan optimisation BHF, Punch force dan Punch velocity, Friction, Blankshape, Forming Limits, Stress dan Strain Distribution, Thickness variation, Defects. Kekuatan blank holder yang optimal sangat penting dalam pembentukan produk micro deep drawing dengan kualitas tinggi. Kerutan dan fraktur akan terjadi ketika gaya blank holder yang diberikan terlalu kecil atau terlalu tinggi untuk kecepatan drawing yang diberikan. Batas atas awal tekanan yang diijinkan blank holder meningkat dengan meningkatnya kecepatan punch. Koefisien gesekan dalam micro deep drawing menurun dengan meningkatnya kecepatan punch seperti yang diketahui pada deep drawing makro sehingga pengaruh koefisien gesekan tergantung kecepatan punch (Vollertsen dkk, 2004). Misalnya, dalam pembentukan tembaga, tepi cup akan berkerut ketika BHF kurang dari 4,2 N dan ketika BHF lebih tinggi dari 5,6 N bagian bawah cup akan retak. Dalam penelitian Irthiea dkk (2014) pengaruh kondisi gesekan dipelajari melalui simulasi numerik dengan menggunakan 
model gesekan Coulomb dengan nilai yang berbeda secara terpisah untuk setiap koefisien gesekan pada bagian antarmuka blank/holder, blank/rubber dan blank/contact punch. Mengenai efek koefisien gesekan $(\mu \mathrm{BH})$ pada antarmuka blank/holder, nilai-nilai 0 dan 0,25 didefinisikan untuk koefisien gesekan pada bagian blank/ rubber dan antarmuka blank/punch. Pada penelitian Saotome dkk (2001) tentang drawability dilakukan menggunakan baja lembaran sangat tipis dengan ketebalan 0,05, 0,1, 0,2 dan 1,0 mm. Diameter punch Dp berkisar 0,5 hingga $40 \mathrm{~mm}$. Diameter punch relatif terhadap ketebalan Dp/t dipilih sebagai parameter eksperimental penting dan dipilih dari 10 hingga 100. Drawability dievaluasi, dan hukum kesamaan dalam deep drawing adalah telah diperiksa. Dan hasilnya adalah sebagai berikut: (1) dalam rentang dari Dp / t $=10$ hingga 100, LDR $\beta=$ Ds / Dp berkurang dengan meningkatnya Dp/t, (2) hukum persamaan dari deep drawing logam tipis adalah diadaptasi dalam kisaran di atas Dp $/ \mathrm{t}=40$. Mekanisme drawing di bawah Dp / t $=20$ harus berbeda dari Dp/t di atas 40., (3) Untuk Dp / t $=10$ dan $\mathrm{Rd} / \mathrm{t}=5,0$, yang dominan adalah bending mekanisme pembentukan karena efek tekanan blank bolder pada drawability ditemukan minimal dan tekanan tidak berpengaruh pada kerja materi selama paruh kedua proses drawing.

Untuk menghasilkan komponen mikro dengan fitur yang lebih kompleks dan standar kualitas dan fungsionalitas yang tinggi di perlukan penelitian dan pengembangan proses micro forming yang terbaru dan inovatif sehingga dapat memenuhi permintaan pasar.

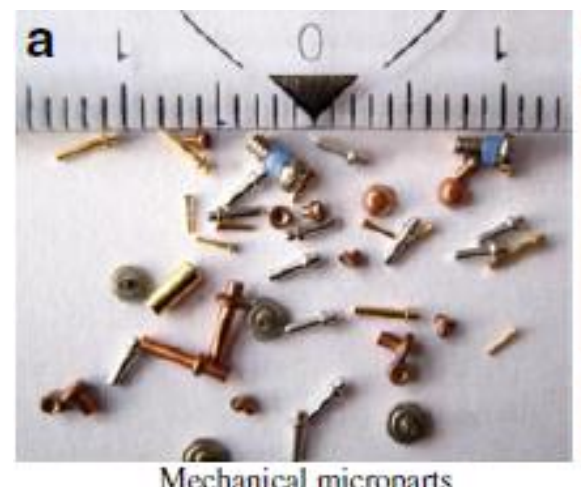

Mechanical microparts

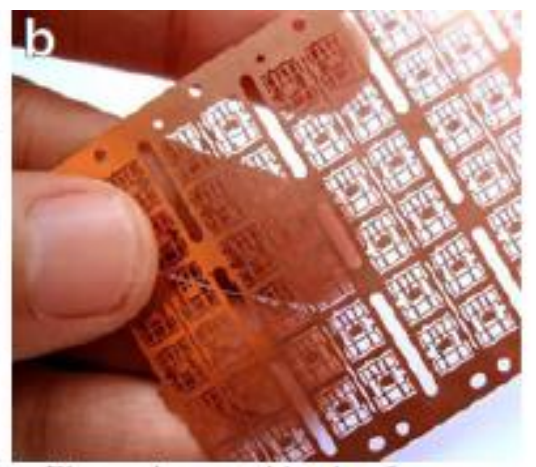

Electronic part with microfeatures

Gambar 2. Micropart industri

Teknologi micro deep drawing memiliki banyak keuntungan seperti kemampuan untuk mengolah logam metal dengan potensi produksi masal, kualitas produk yang tinggi dan fabrikasi produk logam 3D yang lebih kompleks.

Metode pembentukan logam mikro dengan material lembar tipis dengan sistem pneumatik belum banyak dilakukan. Proses micro deep drawing dari logam tipis dapat diekstrusi pada suhu ruangan tanpa mengurangi kualitas permukaan cup dengan proses micro deep drawing pneumatik. Selama proses micro deep drawing pneumatik dengan kondisi tekanan dan kecepatan drawing sangat berpengaruh terhadap perilaku deformasi brass. Penelitian ini bertujuan untuk membuat cup dari material brass untuk dianalisis kedalaman cup dan cacat akibat di pengaruh besarnya tekanan dan kecepatan punch dalam proses micro deep drawing. 


\section{METODE PENELITIAN}

Tahapan studi ini adalah persiapan dan pemilihan material brass yang digunakan, kemudian dilanjutkan dengan proses pembuatan blank, proses pembuatan spesimen untuk di uji tarik, dan proses pembutan cup dengan mesin micro deep drawing pneumatik. Material brass yang digunakan adalah berupa lembaran brass 70/30 (Yellow brass sheet dari Nilaco Corp) dengan ketebalan $300 \mu \mathrm{m}$ sesuai dengan ASTM B 36/B 36M - 06.

Tabel 1. Komposisi material brass ASTM B 36/B 36M - 06

\begin{tabular}{lllll}
\hline UNS No. & Copper & Lead & Iron & Zinc \\
\hline C26000 & $68,5-71,5$ & 0,07 max & 0,05 max & remainder \\
\hline
\end{tabular}

Lembaran brass dipilih yang baik dengan tidak tertekuk dan tergores. Brass kemudian di potong menjadi strip-strip dilanjutkan dengan proses pembuatan blank dengan diameter $6 \mathrm{~mm}$. Pembuatan blank dilakukan dengan mesin micro punching pneumatik. Kemudian dilakukan penyotiran kembali guna memilih blank yang tidak terdapat kerusakan maupun cacat tekukan maupun berbentuk oval yang disebabkan karena proses blanking.
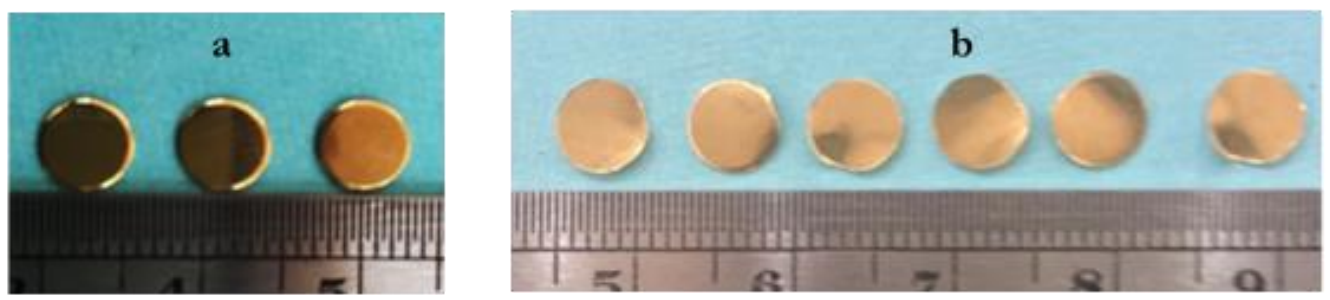

Gambar 3. (a) blank baik, (b) blank rusak

Selain membuat blank juga dilakukan pembuatan specimen untuk pengujian tarik . Uji tarik material Brass 70/30 dilakukan untuk untuk mendapatkan mechanical properties, antara lain nilai UTS (Ultimate Tensile Strength) material yang akan dilakukan proses drawing. Nilai pengujian tarik ini akan digunakan untuk perhitungan menentukan tegangan maksimum yang dibutuh pada proses drawing. Selain itu untuk mendapatkan nilai regangan yang terjadi akibat uji tarik untuk menentukan kedalaman drawing maksimun.
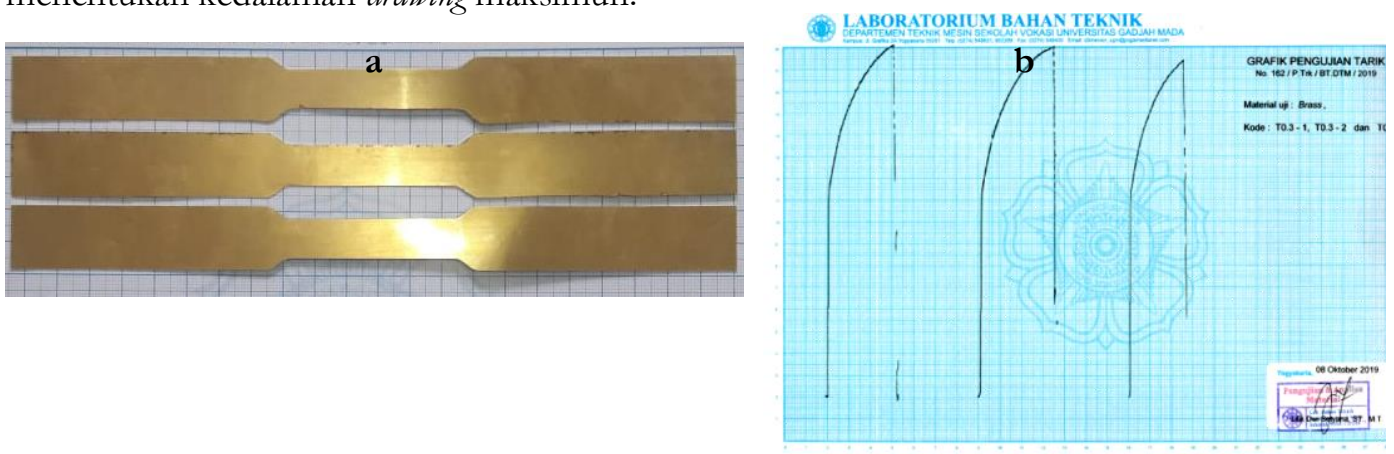

Gambar 4. (a) specimen uji tarik, (b) diagram hasil uji tarik 
Dari pengujian diagram uji tarik didapatkan hasil seperti pada Tabel 2. berikut :

Tabel 2. Hasil uji tarik material brass dengan ketebalan $300 \mu \mathrm{m}$

\begin{tabular}{|l|l|l|l|l|}
\hline No & Kode & Teg. Luluh $\sigma_{\mathrm{y}}(\mathrm{MPa})$ & Teg. Max $\sigma_{\mathrm{u}}(\mathrm{MPa})$ & Regangan $\varepsilon(\%)$ \\
\hline 1. & T0.3-1 & 224,90 & 408,11 & 34,52 \\
\hline 2. & T0.3-2 & 230,42 & 409,64 & 38,28 \\
\hline 3. & T0.3-3 & 226,36 & 391,96 & 29,12 \\
\hline \multicolumn{2}{r|}{ Rerata } & 227,22 & 403,23 & 33,97 \\
\hline
\end{tabular}

* T0.3-1 adalah kode uji tarik sampel ke-1 dengan tebal 0,3 mm

Proses micro deep drawing di awali dengan meletakkan blank pada die. Dengan tekanan dan kecepatan tertentu punch turun kebawah mendekati blank dan kemudian blank holder menekan blank dan punch mendorong tengah bagian blank sehingga membentuk sebuah cup. Setelah cup terbentuk punch ditarik keatas oleh gaya tarik dari pneumatik. Kemudian cup dianalisis dengan mengukur tinggi сир maksimum dan minimum serta cacat yang terjadi akibat proses drawing dengan menggunakan kamera dinolite. Proses ini dapat di ilustrasikan dengan 6 tahapan skematis seperti Gambar 6 berikut ini :

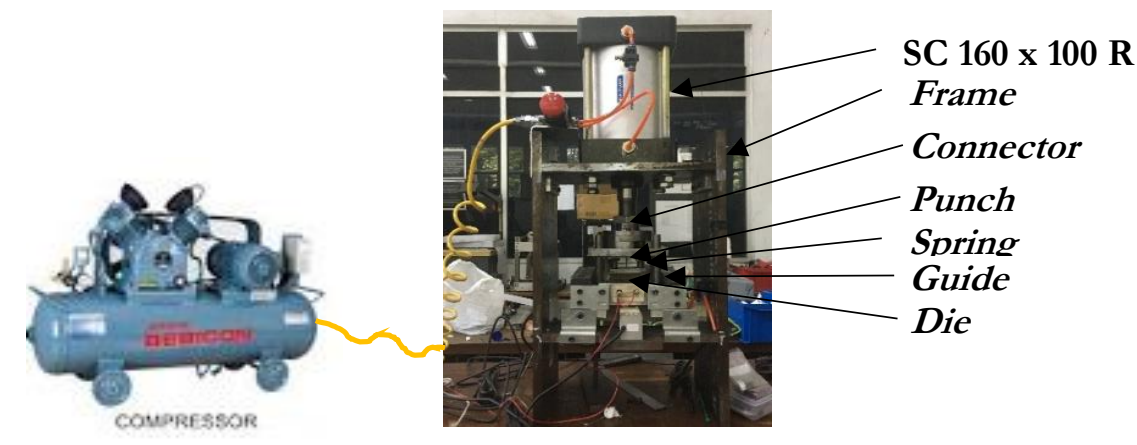

Gambar 5. Mesin micro deep drawing pneumatik
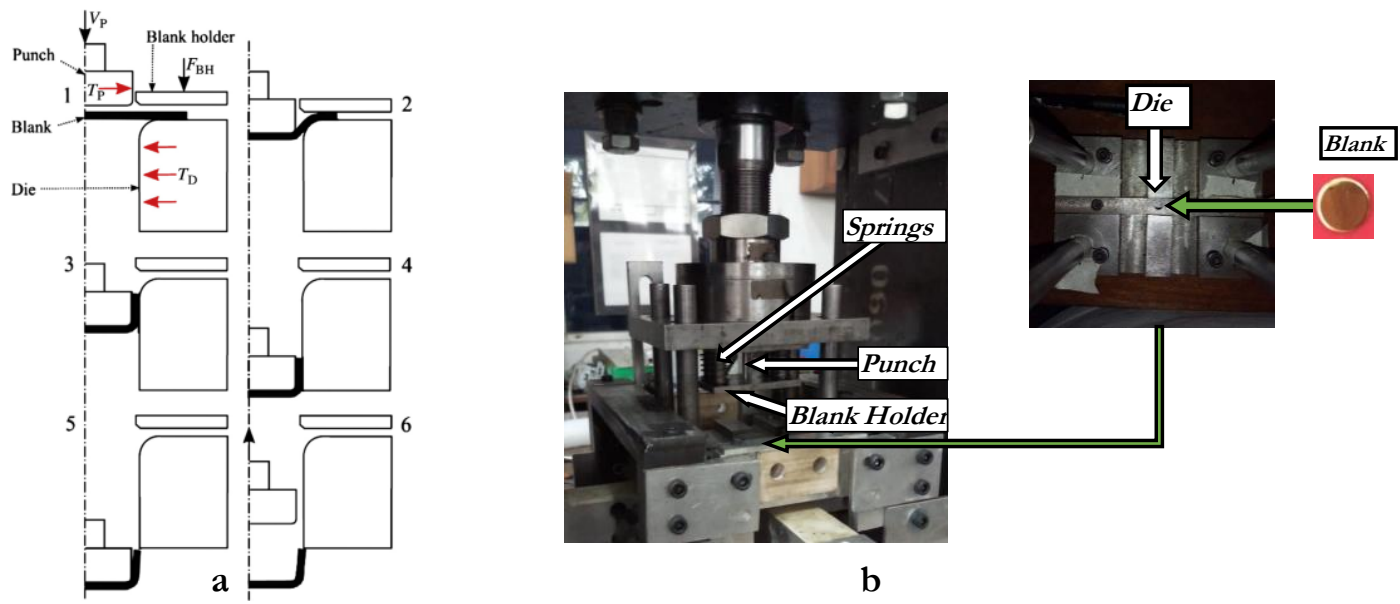

Gambar 6. (a) Skema micro deep drawing (Jiang, 2016) (b) Peletakan blank pada die 


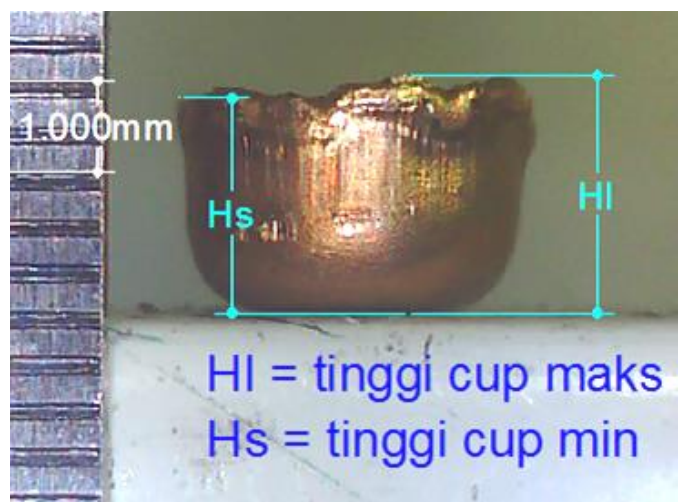

Gambar 7. Cup hasil proses micro deep drawing pneumatik

Pada ekperimen ini tidak memakai chussion/pad dan mengunakan kombinasi tekanan dengan kecepatan punch dalam mendorong blank untuk menghasilkan cup. Kombanasi variabel tekanan 2 bar dengan kecepatan $20 \mathrm{~mm} / \mathrm{s}, 40 \mathrm{~mm} / \mathrm{s}, 60 \mathrm{~mm} / \mathrm{s}$, tekanan 4 bar dengan kecepatan $20 \mathrm{~mm} / \mathrm{s}, 40 \mathrm{~mm} / \mathrm{s}, 60 \mathrm{~mm} / \mathrm{s}$ dan tekanan 4 bar dengan kecepatan $20 \mathrm{~mm} / \mathrm{s}, 40 \mathrm{~mm} / \mathrm{s}, 60$ $\mathrm{mm} / \mathrm{s}$.

Tabel 3. Kondisi ukuran saat penelitian

\begin{tabular}{|c|c|c|c|c|}
\hline Kondisi Material & \multicolumn{3}{|c|}{ Brass $70 / 30$} & Satuan \\
\hline Tebal blank & \multicolumn{3}{|c|}{300} & $\mu \mathrm{m}$ \\
\hline Diameter Punch & \multicolumn{3}{|c|}{3,15} & $\mathrm{~mm}$ \\
\hline Diameter Die & \multicolumn{3}{|c|}{3,94} & $\mathrm{~mm}$ \\
\hline$\overline{\text { Diameter Blank }}$ & \multicolumn{3}{|c|}{6,00} & $\mathrm{~mm}$ \\
\hline Drawing Ratio & \multicolumn{3}{|c|}{1,90} & \\
\hline Gaya blank holder & \multicolumn{3}{|c|}{67,88} & $\mathrm{~N}$ \\
\hline Suhu die and blank bolder & \multicolumn{3}{|c|}{ Suhu ruangan } & ${ }^{\circ} \mathrm{C}$ \\
\hline Tekanan & 2 & 4 & 6 & Bar \\
\hline Kecepatan punch & 20 & 40 & 60 & $\mathrm{~mm} / \mathrm{s}$ \\
\hline
\end{tabular}

\section{HASIL DAN PEMBAHASAN}

Tinggi cup dalam proses micro drawing dapat disebabkan oleh adanya kecepatan dan tekanan punch. Tumbukan yang terjadi antara punch dengan blank. Untuk menghentikan laju punch yang bergerak maka blank timbul gaya yang cukup untuk untuk menghilangkan energi kinetiknya, sehingga memperpanjang ketinggian cup yang didorong punch selama tumbukan sehingga mengurangi gaya tumbukan rata-rata. Bentuk сир yang terjadi adalah bentuk redaman dari energi kinetik yang terjadi. Bertambahnya kecepatan akan menghasilkan energi kinetik yang lebih besar dan semakin besar gaya yang dibutuhkan untuk menghentikannya, sehingga akibat yang ditimbulkannya semakin dalam cup. Hasil dari penelitian ini dapat dilihat pada grafik Gambar 8, 9, dan 10. 


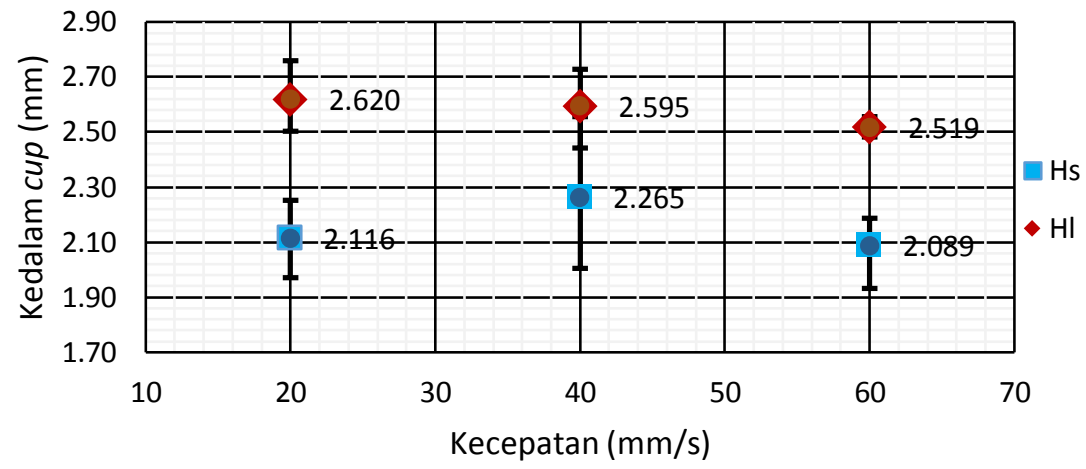

Gambar 8. Grafik kecepatan tehadap kedalaman pada tekanan 2 bar

Kondisi final pada pengujian micro deep drawing memenuhi kriteria apabila kedalaman cup lebih dari setengah dari diameter cup. Pada Gambar 8 saat tekanan 2 bar kecepatan drawing 20 $\mathrm{mm} / \mathrm{s}$ didapatkan $\mathrm{Hl}=2,620 \mathrm{~mm}$ dan $\mathrm{Hs}=2,116 \mathrm{~mm}$, kecepatan $40 \mathrm{~mm} / \mathrm{s}$ didapatkan $\mathrm{Hl}=$ 2,595 $\mathrm{mm}$ dan $\mathrm{Hs}=2,265 \mathrm{~mm}$ dan kecepatan $60 \mathrm{~mm} / \mathrm{s}$ didapatkan $\mathrm{Hl}=2,519 \mathrm{~mm}$ dan $\mathrm{Hs}=$ 2,089 mm. Berdasarkan hasil Gambar 8 pada tekanan 2 bar maka kecepatan optimum untuk menghasilkan cup yang baik adalah kecepatan $40 \mathrm{~mm} / \mathrm{s}$.

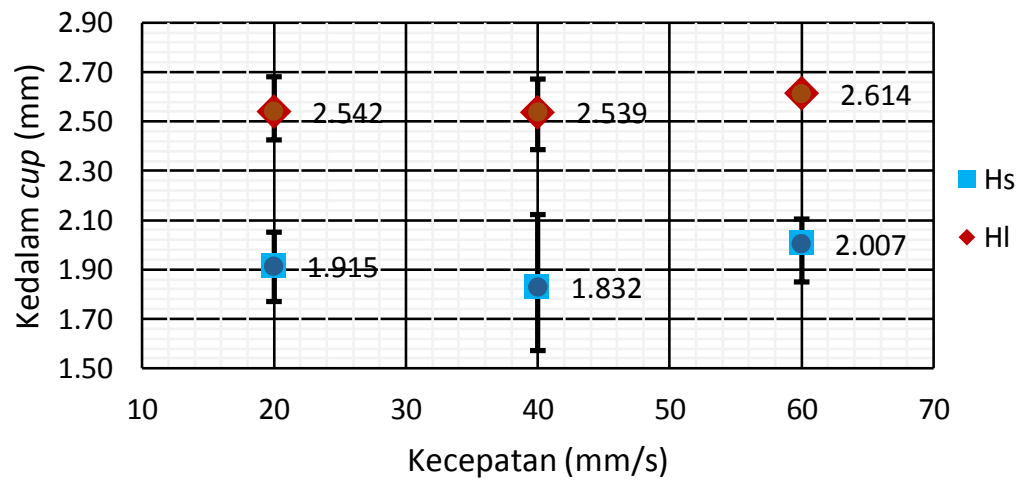

Gambar 9. Grafik kecepatan tehadap kedalaman pada tekanan 4 bar

Pada Gambar 9 saat tekanan 4 bar kecepatan drawing $20 \mathrm{~mm} / \mathrm{s}$ didapatkan $\mathrm{Hl}=2,542$ $\mathrm{mm}$ dan $\mathrm{Hs}=1,915 \mathrm{~mm}$, kecepatan $40 \mathrm{~mm} / \mathrm{s}$ didapatkan $\mathrm{Hl}=2.539 \mathrm{~mm}$ dan $\mathrm{Hs}=1,832$ $\mathrm{mm}$ dan kecepatan $60 \mathrm{~mm} / \mathrm{s}$ didapatkan $\mathrm{Hl}=2,614 \mathrm{~mm}$ dan tinggi cup Hs $=2,007 \mathrm{~mm}$. Hasil Gambar 9 menunjukan bahwa untuk tekanan 4 bar kecepatan optimum untuk menghasilkan cup yang baik adalah kecepatan $60 \mathrm{~mm} / \mathrm{s}$ 


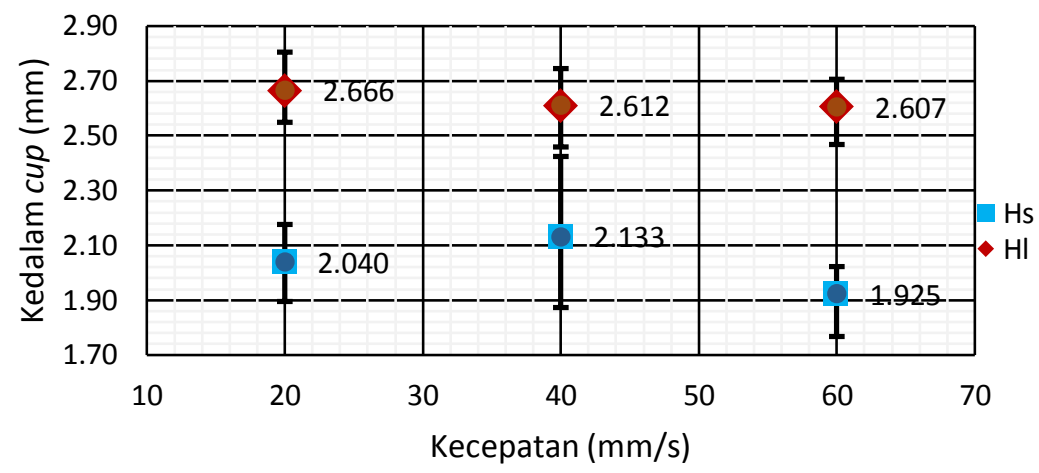

Gambar 10. Grafik kecepatan tehadap kedalaman pada tekanan 6 bar

Pada Gambar 10 saat tekanan 6 bar kecepatan drawing $20 \mathrm{~mm} / \mathrm{s}$ didapatkan $\mathrm{Hl}=$ 2,666 $\mathrm{mm}$ dan $\mathrm{Hs}=2,040 \mathrm{~mm}$, kecepatan $40 \mathrm{~mm} / \mathrm{s}$ didapatkan $\mathrm{Hl}=2,607 \mathrm{~mm}$ dan $\mathrm{Hs}=2,133 \mathrm{~mm}$ dan kecepatan $60 \mathrm{~mm} / \mathrm{s}$ didapatkan $\mathrm{Hl}=1,925 \mathrm{~mm}$ dan $\mathrm{Hs}=2,007 \mathrm{~mm}$. Berdasarkan hasil Gambar 10 bahwa untuk tekanan 6 bar kecepatan optimum untuk menghasilkan cup yang baik adalah kecepatan $20 \mathrm{~mm} / \mathrm{s}$.

Dari hasil pengamatan dapat dibuat tabulasi cacat yang di sebabkan oleh proses micro deep drawing. Dari semua benda uji tidak terdapat wrinkling dan tearing hal ini disebabkan karena tebal blank adalah $300 \mu \mathrm{m}$.

Tabel 4. Kondisi cup setelah proses micro deep drawing

\begin{tabular}{|c|c|c|c|c|}
\hline \multirow{2}{*}{$\begin{array}{c}\text { Tekanan } \\
\text { (Bar) }\end{array}$} & \multirow{2}{*}{$\begin{array}{c}\text { Kecepatan } \\
(\mathrm{mm} / \mathrm{s})\end{array}$} & \multicolumn{3}{|c|}{ Defect } \\
\hline & & Wrinkling & Earing & Tearing \\
\hline \multirow{3}{*}{$\frac{\text { हैं }}{\text { กे }}$} & 20 & $x$ & $x$ & $x$ \\
\hline & 40 & $x$ & $x$ & $x$ \\
\hline & 60 & $x$ & $x$ & $x$ \\
\hline \multirow{3}{*}{$\frac{\text { है }}{\partial}$} & 20 & $x$ & $x$ & $x$ \\
\hline & 40 & $x$ & o & $x$ \\
\hline & 60 & $x$ & o & $x$ \\
\hline \multirow{3}{*}{$\frac{\vec{ే}}{0}$} & 20 & $x$ & o & $x$ \\
\hline & 40 & $x$ & o & $x$ \\
\hline & 60 & $x$ & $\mathbf{o}$ & $x$ \\
\hline
\end{tabular}

$\times=$ tidak terjadi

$\mathbf{O}=$ terjadi 
R. Diwihagso dan M. Mahardika / Journal of Mechanical Design and Testing 2(1), (2020), 37-45

\section{KESIMPULAN}

Dari hasil pengujian dapat disimpulkan bahwa kecepatan dan tekanan sangat berpengaruh terhadap kedalaman сир. Perpaduan tekanan dan kecepatan dapat menghasilkan bentuk cup yang baik pada kondisi tekanan 2 bar dengan kecepatan $40 \mathrm{~mm} / \mathrm{s}$ dengan kedalaman maksimum 2,595 $\mathrm{mm}$ dan kedalaman minimum 2,265 mm sehingga selisihnya 0,33 mm sehingga relatif lebih rata. Cup yang baik adalah tidak terdapat kerusakan pada dinding dan bagian bawah cup. Radius punch sangat berpengaruh sekali terhadap kerusakan yang akan terjadi pada radii cup. Kerusakan akibat dari proses drawing terjadi akibat blank holder force terlalu rendah sehingga blank yang dibentuk menjadi cup menjadi earing. Kondisi paling kritis terjadi pada daerah radii dari cup, karena di daerah tersebut terdapat dua kombinasi tegangan radial dan tegangan tangensial yang harus dijaga secara seimbang.

\section{DAFTAR PUSTAKA}

Fu, M. W., Chan. W. L, 2013 A review on the state-of-the-art microforming technologies, Int J Adv Manuf Technol 67:2411-2437.

Https://semiengineering.com/health-growth-ahead-in-mems, 17 juni 2019

Irthiea, Ihsan Khalaf (2014) Process analysis and design in micro deep drawing utilizing a flexible die. PhD thesis.

Luo.L, Jiang.Z, Wei.D, . Manabe. K.I, Sato.H, He.X, Li.P., 2015, An experimental and numerical study of micro deep drawing of SUS304 circular cups.

Saotome.Y, Yasuda.K, Kaga.H., 2001, Microdeep drawability of very thin sheet steels, Journal of Materials Processing Technology 113, page 641-647.

Sridhar R., Inbarasan S., Ramkumar R., Shankar S., Review on micro deep drawing process for thin foil materials, International Joumal of Innovations in Engineering and Technology (IJIET).

Vollertsen,F., Hu,Z., Niehoff,H. , Schulze,H., Theiler,C., vol. 151, pp. 70-79, 2004, State of the art in micro forming and investigations into micro deep drawing, Journal of Materials Processing Technology. 